\title{
Phenotypic characterization and genome-wide association studies of digital cushion thickness in Holstein cows
}

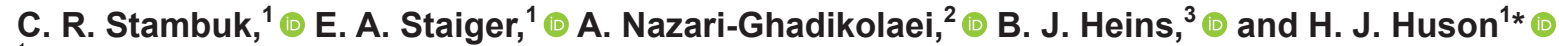 \\ ${ }^{1}$ Department of Animal Science, Cornell University, Ithaca, NY 14853 \\ ${ }^{2}$ Department of Animal Science, College of Agriculture and Natural Resources, University of Tehran, Karaj 77871-31587, Iran \\ ${ }^{3}$ Department of Animal Science, University of Minnesota, St. Paul 55108
}

\begin{abstract}
The bovine digital cushion is a compression pad between the distal phalanx and sole and has been associated with claw horn disruption lesions. Digital cushion thickness (DCT) is estimated to be moderately heritable. Therefore, the objectives of our study were to examine influences of management and environment on DCT and to identify genetic markers and candidate genes associated with DCT. In a cohort of 502 Holsteins from 5 farms in New York State, DCT and body condition score (BCS) were collected twice, at $<137 \mathrm{~d}$ prepartum and from 86 to $127 \mathrm{~d}$ in milk, corresponding to periods when the digital cushion is thickest and thinnest, respectively, as determined by previous research. Cows underwent sonographic examination of the digital cushion evaluated at the typical sole ulcer site for the right front and hind foot. Linear mixed models were conducted on DCT with the fixed effects of time point, digit, wither height, sacral height, BCS group, and multiple farm system variables separately and included random effects to control for the random subset of cows per farm, repeated measures, and multiple measurements from each cow. The phenotypic results indicated that DCT varied by sample time point, sacral height, parity, digit, BCS group, and wither height. For the genotypic study, 447 DNA samples were genotyped on the Illumina BovineHD 777K BeadChip (Illumina Inc., San Diego, CA). Quality assessment of markers and samples provided a final data set of 431 samples and 579,449 markers. Genome-wide association studies were conducted for DCT testing inheritance models and genetic variation of digit, foot, time point, and average thickness. One marker passed the Bonferroni correction threshold and 26 passed false discovery rate from 4 genome-wide association studies with covariates of sequencing batch plate, parity group, BCS, wither
\end{abstract}

Received August 5, 2019.

Accepted December 10, 2019.

*Corresponding author: hjh3@cornell.edu height, and sacral height. Ten candidate genes were identified, with 2 genes on Bos taurus autosomes 24 and 29 involved in biological functions related to the digital cushion: $M C 4 R$ and $D L G 2$ were related to fat deposition and bone growth, respectively. The genetic markers discovered in this study have the opportunity to be used in breeding programs using genomic selection to select against claw horn disruption lesions and lameness due to associations between the markers and DCT. Further studies on the biologically plausible candidate genes may identify causative genetic variants and how they relate to DCT through gene regulation, expression, structure, or copy number variation.

Key words: dairy cattle, claw horn disruption lesion, lameness, gene, marker

\section{INTRODUCTION}

The digital cushion is an important structure in dampening the compression of the corium tissue that produces the sole horn under the distal phalanx (Lischer et al., 2002; Räber et al., 2004; Shearer et al., 2015). It is a complex structure comprising mostly adipose and connective tissue (Räber et al., 2004). Approximately $90 \%$ of the digital cushion lies behind the navicular bone in the heel area, whereas only $10 \%$ extends forward beneath the distal phalanx (Mülling and Greenough, 2006). Digital cushion thickness (DCT) at the typical sole ulcer site beneath the distal phalanx has been shown to be a strong predictor of lameness and the claw horn disruption lesions (CHDL) of sole ulcers and white line disease (Bicalho et al., 2009; Newsome et al., 2017a,b; Stambuk et al., 2019). These CHDL are the most prevalent claw diseases associated with lameness and pain (Murray et al., 1996; Oikonomou et al., 2013).

Previous studies are inconsistent on what thickness is optimum. Bicalho et al. (2009) and Newsome et al. (2017a,b) determined that thin digital cushion measurements predispose animals to lameness and lesions later in lactation. However, they measured only the hind feet and used an average DCT. Stambuk et al. (2019) discovered that DCT varied by digit and that 
particular digits of certain thickness increased the odds of lameness or noninfectious lesions in lactation. For example, cows that had an average DCT of the front lateral digit measured at 1 to 30 DIM had higher odds of lameness $(11.5 \times)$ than cows with thin DCT of the same digit.

Selecting for healthier digital cushions could have a faster rate of genetic gain and greater effect on decreasing the occurrences of CHDL and lameness on farms than selecting against certain lesions separately due to the higher heritability of DCT than CHDL and lameness determined by visual locomotion scores. Digital cushion thickness was previously determined to be moderately heritable $(0.33 \pm 0.09)$ and had a negative genetic correlation with CHDL $(-0.60 \pm 0.29$; Oikonomou et al., 2014). Heringstad et al. (2018) reviewed multiple studies and found heritability estimates for CHDL ranging from 0.01 to 0.12. Sprecher et al. (1997) estimated that the heritability of lameness according to visual locomotion scoring ranged from 0.07 to 0.10 . Thus far, only one other study has investigated the genetics of DCT. Iqbal et al. (2016) specifically investigated the effect of diet on the expression of 27 candidate genes in the digital cushion from a small cohort of nonpregnant, nonlactating dairy cows and found that feeding a higher energy diet consistently upregulated lipogenic genes. However, the genetics behind the thickness of the digital cushion beneath the distal phalanx in pregnant and lactating cows from multiple farms have not been studied. Therefore, the objectives of our study were (1) to examine influences of management and environment on DCT across multiple farms and (2) to identify genomic regions associated with DCT and how they might differ by foot, digit, or stage in lactation.

\section{MATERIALS AND METHODS}

Approval from the Cornell University Institutional Animal Care and Use Committee (protocol no. 20140121) and signed owner consent were obtained before commencement of this study. Data were collected from a convenience sample of 5 commercial dairy farms located near Ithaca, New York, from October 13, 2015, to October 26, 2017. The farms were selected based on easy access to cows, hoof trimmers, chutes, and willingness of farm owners and managers to accommodate the study. Cow data and management systems are outlined in Table 1. The total number of cows ranged from 150 to 4,400 per farm. The cows walked a distance of 3.5 to $379 \mathrm{~m}$ to the milking parlor 2 to 3 times per day, and production ranged from 39 to $42 \mathrm{~kg}$ of milk/cow per day. All cows were housed in freestall barns with bedding that included paper fiber, sawdust, sand, or manure solids. All farms were on a routine schedule to have cows trimmed by a hoof trimmer at least twice per year, mostly at mid lactation and dry-off (Table 1). All lame cows on the farms were treated when identified as lame by farm employees.

\section{Data Collection and Study Design}

A total of 502 Holstein cows were enrolled in a prospective cohort study in which DCT measurements were evaluated at 2 time points. Not all cows on the farms were sampled for this study. Cows were randomly selected based on the availability of cows at or near dryoff on farm as well as cows that were undergoing hoof trimming on the day of the herd visits. The number of cows per farm depended on the total number of cows on farm, the schedule of cow hoof trimming, the schedule of the hoof trimmer, and the number of cows that could be seen by the hoof trimmer and researcher at the same time per visit. The convenience sample contained more multiparous cows than primiparous cows. Of the 5 farms, 2 contributed $64 \%$ of the cows almost equally, whereas the other 3 farms had similar contribution in the number of cows representing the remaining $36 \%$. The first measurement was $<137 \mathrm{~d}$ prepartum (DPP), when cows are near or in the dry period before calving. This time period corresponds to when the digital cushion has been found to be thicker in primiparous and multiparous cows (Bicalho et al., 2009; Stambuk et al., 2019). This measurement had a mean $( \pm$ SD) of $47.6 \pm 25.8 \mathrm{DPP}$ and a range of 1 to $136 \mathrm{DPP}$, with $90 \%$ of the cows being sampled between 1 and 77 DPP. Figure 1 shows the range in the number of cows for DPP. The majority of cows were sampled from 10 to 40 and 50 to $90 \mathrm{DPP}$. The large variation in DPP was due to the farms' trimming schedule and management practices. Multiparous cows that were not in the dry period at the first measurement were $>250$ DIM. Six cows did not have a DPP for the first time point because they died or were culled before calving but were 204 to $226 \mathrm{~d}$ carried calf at the first time point. The second measurement occurred in early to mid lactation from 86 to 127 DIM when DCT was found to be thinnest and coincided with routine hoof trimming schedules to minimize the effect on the cows and farm management (Bicalho et al., 2009; Stambuk et al., 2019).

Hoof trimming was completed by contracted professionals or trained farm employees, and cows were restrained for hoof trimming using either a standing chute or a tilt table. Two farms had an Appleton Steel Trimming Chute (Appleton Steel, Appleton, WI), 1 farm had a Comfort Chute H-series (Comfort Hoof Care, Baraboo, WI), and 2 farms trimmed cows on a layover Riley Built trailer model hoof trimming chute (Riley Built, Lubbock, TX). 
Stambuk et al.: GENETICS OF DIGITAL CUSHION THICKNESS

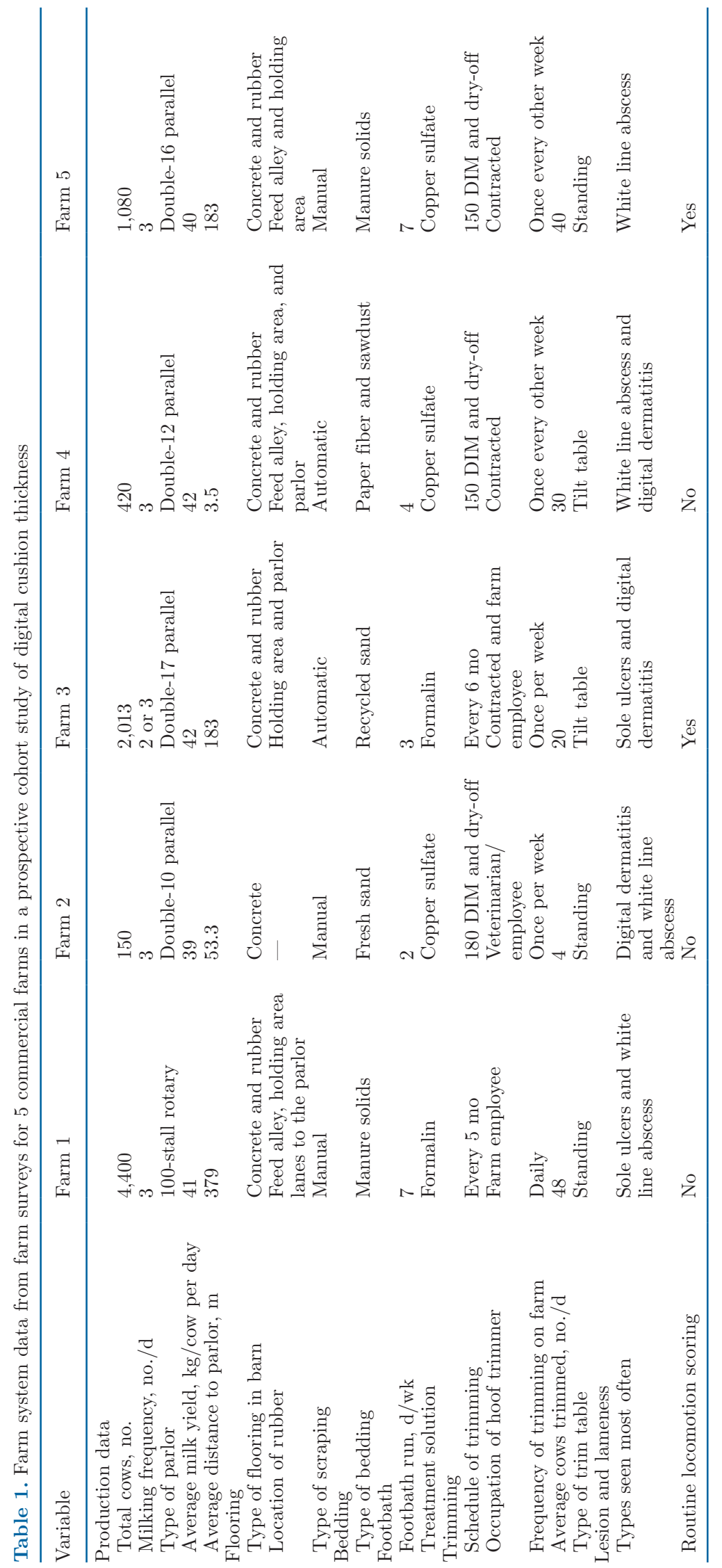


At each measurement, a single trained researcher collected BCS, which ranged from 1 to $5(1=$ emaciated and $5=$ severely overconditioned), with a quarter-point system as described by Edmonson et al. (1989). Cow height was assessed at both wither and sacral heights, which were determined by the distance from the floor to the withers and the distance from the floor to the dorsal aspect of the caudal sacral joint, respectively. Wither height and sacral height were measured at the beginning of the study. Parity, DIM at each measurement event, and calving date were obtained from the farm management software (DairyComp 305; Valley Agricultural Software, Tulare, CA). The cows underwent digital sonographic B-mode examination with an Aquila Vet ultrasound machine (Esaote Europe BV, Maastricht, the Netherlands) of the 4 right digits immediately after trimming. The measurement was collected at the typical sole ulcer site located beneath the flexor tuberosity in the medial aspect of the middle pad, evaluating the distance from the inner margin of the sole to the distal edge of the tuberculum flexorum of the third phalanx (Bicalho et al., 2009; Stambuk et al., 2019).

\section{Variable Definitions}

All measurements for BCS and cow height in the final data set were categorized into terciles separately to facilitate interpretation of applied variables by dairy farmers (Oikonomou et al., 2013; Stambuk et al., 2019). The BCS were categorized into BCS groups (BCSG): $1=\mathrm{BCS}<2.75,2=\mathrm{BCS} \geq 2.75$ and $\leq 3.25$, and $3=$ BCS $>3.25$. Both wither height and sacral height were categorized as short if height was $<145 \mathrm{~cm}$, average if height was $\geq 145$ and $\leq 150 \mathrm{~cm}$, or tall if height was $>150 \mathrm{~cm}$. Time point was either 1 for $<137$ DPP or 2 for 86 to 127 DIM. Parity was 1 for cows in first lactation and 2 for cows in lactation $>1$. The variable digit (DGT) represented the specific hoof digits and was categorized as front medial, front lateral, hind medial, and hind lateral. All variables for statistical analysis of DCT were cow-level variables. Management characteristics for statistical analysis were based on a survey of farm-level variables.

\section{Statistical Analysis}

Before any statistical analysis, 6 cows were excluded from the data set because their sampling occurred outside targeted time points. Data from 496 cows were used in the statistical analyses, with 104 primiparous cows and 392 multiparous cows at the first measurement time point. The second measurement time point included data from 97 primiparous and 349 multiparous cows. The difference in the cow numbers sampled between the 2 time points was due to culling or mortalities on the farm. Within this project, primiparous cows were those that were nulliparous at the first time point and that transitioned to primiparous before the second time point. When evaluating the number of experimental units needed to observe meaningful differences, a sample size of 496 cows was calculated to show an expected difference with an associated $P$-value of 0.05 (assuming power $=0.97, \alpha=0.05,1$-way ANOVA). Rather than including multiple fixed effects in a single model, our goal was to describe how each variable influenced DCT independently. We could not evaluate the association between DCT and lameness or noninfec-

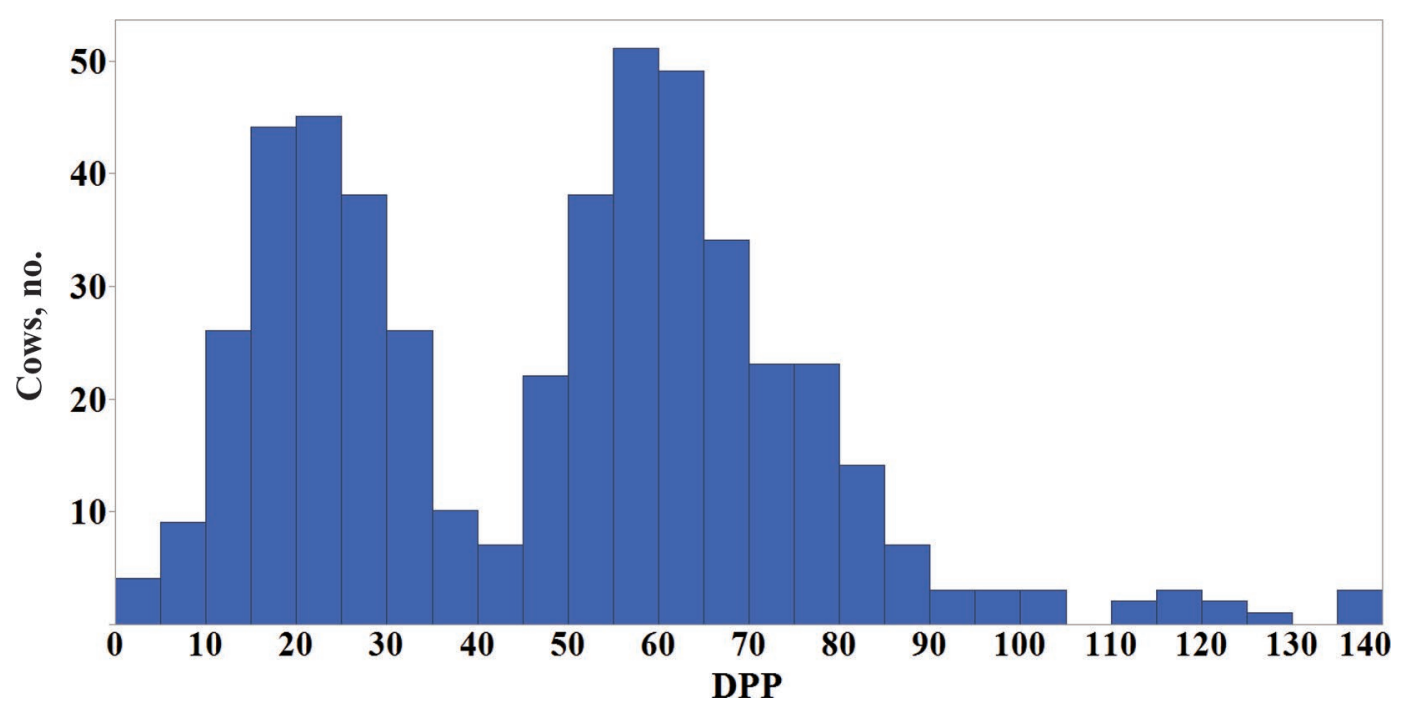

Figure 1. Range of days prepartum (DPP) for Holstein cows for digital cushion thickness measurements. 
tious lesions due to the relatively low incidences $(<15 \%$ for either), particularly when the cases were broken down to the parity-farm subclasses $(<5$ either lameness events or lesions occurred in the primiparous cows per parity-farm subclass).

Mixed-model methodology was used (PROC MIXED; SAS University Edition, SAS Institute Inc., Cary, NC) to analyze the data in this study. The fixed effects evaluated separately were time point $(<137$ DPP or 86 to 127 DIM) reflecting lactation stage for each cow sampled, DGT (front medial, front lateral, hind medial, hind lateral), sacral height (short, average, tall), wither height (short, average, tall), BCSG (thin, average, fat), and the herd management characteristics of milking parlor type (parallel or rotary), milk production category ( $\leq 41$ or $>41 \mathrm{~kg}$ ), bedding type (manure solids, sand, sawdust), flooring type (rubberized or nonrubberized in feed alley), manure scraping system (manual or automatic), footbath length category ( $<4$ or $\geq 4 \mathrm{~m}$ ), visual locomotion score captured category (yes or no), trimming chute type (standing or layover), and hoof trimmer category (contractor, farm employee, or veterinarian/employee). To evaluate how each management characteristic influenced DCT rather than generalizing the effect to farm, factors were evaluated individually.

The following general model was used for all analyses:

$$
Y_{i j k l m}=\mu+V_{i}+P_{j}+V P_{i j}+F_{k}+C_{l}+e_{i j k l m},
$$

where $Y_{i j k l m}$ is the observed values for DCT, $\mu$ is the overall population mean, $V_{i}$ is a fixed effect for each of the independent variables under consideration that were included in the model singularly, $P_{j}$ is the fixed effect of parity group, $V P_{i j}$ is the interaction of parity group and the independent variable being evaluated, $F_{k}$ is the random effect of farm, $C_{l}$ is the random effect of cow nested within farm, and $e_{i j k l m}$ is the random residual error. All independent variables and parity group (primiparous or multiparous) were included as fixed effects in the model along with the interaction term between the 2 variables. All models included the random effects of farm and cow nested within farm. The model with time point included the additional random effect of DGT nested within farm due to the repeated measures of time points for cows and claw (4 digits evaluated at each time period). The model with DGT included the additional random effect of time point nested within farm because claw measures were repeated across time (2 time points evaluated for each claw). The models with wither height, sacral height, BCSG, and herd management characteristics included the additional random effects of time point nested within farm and DGT nested within farm. The autoregressive covariance structure was used for measurements across time for all models because it resulted in the lowest Akaike information criterion (Littell et al., 1998). Pairwise mean comparisons evaluated significant effects in all models, and $P$-values were adjusted for multiple comparisons using the Tukey-Kramer method. All treatment results were reported as least squares means, with significance declared at $P<0.05$.

\section{Genotyping and Quality Control}

Whole blood $(10 \mathrm{~mL})$ was obtained via the coccygeal vessels into Vacutainer tubes with the anticoagulant $\mathrm{K}_{2}$ EDTA for subsequent DNA extraction (Vacutainer K2 EDTA; BD, Franklin Lakes, NJ). Genomic DNA was extracted following the Gentra Puregene Blood Kit extraction protocol (Qiagen, Valencia, CA). A total of 447 samples were genotyped on the Illumina BovineHD 777K BeadChip (Illumina Inc., San Diego, CA) at GeneSeek (Neogen Genomics, Lincoln, NE). One sample was dropped for breed misidentification. The initial 777,962 SNP were assessed for quality using Golden Helix SVS version 8.8.3 (Golden Helix, Bozeman, MT). A total of $198,513 \mathrm{SNP}$ were removed based on a call rate of $<0.90$ $(\mathrm{n}=9,341 \mathrm{SNP})$, a minor allele frequency of $<0.05$ ( $\mathrm{n}$ $=188,415$ SNP), and a Hardy-Weinberg equilibrium $P$-value of $<0.0001$ ( $\mathrm{n}=65,140 \mathrm{SNP})$. Twelve samples were subsequently removed with a genotyping call rate of $<0.90$. To evaluate population structure and relatedness, an identity-by-state similarity matrix was used to calculate genome-wide identity-by-descent estimates (Purcell et al., 2007). Three animals were removed with an estimated identity-by-state score of $>0.85$ denoting substantial relatedness. The final data set included 431 samples and 579,449 SNP.

\section{Genome-Wide Association Studies}

Digital cushion thickness was defined as the measurements of each claw and time point $(\mathrm{n}=8 ; 4$ claws at 2 times points) and the averages of claw $(\mathrm{n}=4)$, time point $(\mathrm{n}=2)$, foot $(\mathrm{n}=2$; front and hind), and all measurements combined $(n=1)$ to test whether genomic regions associated with averaging the measurements captured more genetic variation underlying DCT than the separate measurements by time point and claw and to explore relationships between genomic regions related to digit, foot, or time point. Digital cushion thickness was evaluated as a quantitative measure. We determined SNP heritability and the power to predict an association between DCT measurements and SNP for the 17 trait definitions of DCT, including the covariates of sequencing batch plate, parity group, BCS, 
wither height, and sacral height, using GCTA (Yang et al., 2011). Single nucleotide polymorphism heritability is the proportion of phenotypic variance attributable to the additive effects of a given set of SNP and is calculated by fitting variance components models with REML estimation (Hou et al., 2019). The formula for calculating SNP heritability is

$$
h^{2}=\sigma_{g}^{2} /\left(\sigma_{g}^{2}+\sigma_{e}^{2}\right)
$$

where $\sigma_{g}^{2}$ is the genetic variance and $\sigma_{e}^{2}$ is the variance due to the environment (Zaitlen and Kraft, 2012). The statistical power of estimating genetic correlation using genome-wide SNP is calculated using the sample size, SNP heritability, type 1 error, and the variance of SNPderived genetic relationships (Visscher et al., 2014). If the statistical power was $>0.80$, then the trait was evaluated in a GWAS. Associations were calculated using EMMAX algorithms embedded in the Golden Helix SVS software to correct for population structure and relatedness by including a genomic relationship matrix as a random effect in the models (Kang et al., 2010). Golden Helix SVS software may test for additive, dominance, and recessive hypothesis, and incidence matrices are accordingly modified during calculations. The mixed model EMMAX uses the following general equation:

$$
\mathbf{y}=\mathbf{X} \boldsymbol{\beta}+\mathbf{Z u}+\mathbf{e},
$$

where $\mathbf{y}$ is an $\mathrm{n} \times 1$ vector of observed phenotypes; $\mathbf{X}$ is an $\mathrm{n} \times \mathrm{f}$ matrix of fixed effects including mean, SNP, and other covariates; $\boldsymbol{\beta}$ is an $\mathrm{f} \times 1$ vector representing coefficient of the fixed effects; $\mathbf{Z}$ is an $\mathrm{n} \times \mathrm{t}$ matrix relating the instances of the random effect to the phenotypes; $\mathbf{u}$ is the unknown random effect of the mixed model with $\operatorname{Var}(\mathbf{u})=\sigma_{g}^{2} \mathbf{K}$, where $\mathbf{K}$ is the kinship matrix inferred from the genotype; and $\mathbf{e}$ is an $\mathrm{n} \times \mathrm{n}$ matrix of residual effect that cannot be explained by the variables in the model (Kang et al., 2008). For the EMMAX mixed model, the effect for each SNP is small, and thus the variance components are calculated for the whole GWAS analysis. The EMMAX model is a pure transposition of a model suggested by Kennedy et al. (1992).

Results from the phenotypic models informed the covariates used in the GWAS models. Association studies with the covariates of sequencing batch plate, parity group, BCS, wither height, and sacral height were considered in additive, dominant, and recessive inheritance models. The covariate of farm was investigated but could not be included with sequencing batch plate because they were highly correlated. Sequencing batch plate accounts for the differences based on sequencing batch as well as farm because one batch contained samples from only 1 farm, whereas the other batch included samples from the other 4 farms. Likewise, individual farm variables (e.g., production, bedding) were highly correlated with farm and therefore captured within the sequencing batch plate variable. Body condition score was an average between the 2 time points to have 1 value for BCS in the GWAS models. The average BCS and wither and sacral heights were kept as continuous measurements.

Quantile-quantile plots were used to determine the model of best fit for each trait and inheritance model and to graphically assess the number and magnitude of observed associations between genotyped SNP and DCT compared with the expected $P$-values from the null hypothesis. Pseudo-lambda values calculated by the Golden Helix SVS software were evaluated as a measure of inflation in the model to verify correction of population stratification, with values around 1 showing no inflation and values $>1.1$ showing inflation. Bonferroni-adjusted $P$-value or false discovery rate (FDR)-adjusted $P$-value of $<0.05$ distinguished SNP significantly associated with DCT. Candidate regions were examined for putative candidate genes based on the linkage disequilibrium (LD) structure or, if $\mathrm{LD}$ was not present, a $1-\mathrm{Mb}$ window centered on the significantly associated SNP using the Bos taurus ARS-UCD1.2 assembly in the NCBI Genome Data Viewer (https:// www.ncbi.nlm.nih.gov/genome/82).

\section{RESULTS}

\section{Descriptive Statistics}

Table 2 shows means and standard deviations of Holstein cow measurements for the 5 commercial dairy farms. Cow measurements include DCT, parity, BCS, and wither and sacral heights.

\section{Linear Mixed Models of DCT}

Variables Without Parity Interactions Associated with DCT. The interactions of measurement time point or sacral height with parity group did not exceed the threshold of $P<0.05(P=0.12$ and 0.67 , respectively). Digital cushion thickness varied by time point and sacral height separately $(P<0.05)$. Digital cushion thickness was thicker at $<137$ DPP than at 86 to 127 DIM $(P<0.001)$. Cows that had greater sacral height had greater DCT compared with those with short or average sacral height $(P<0.05$; Table 3$)$. 


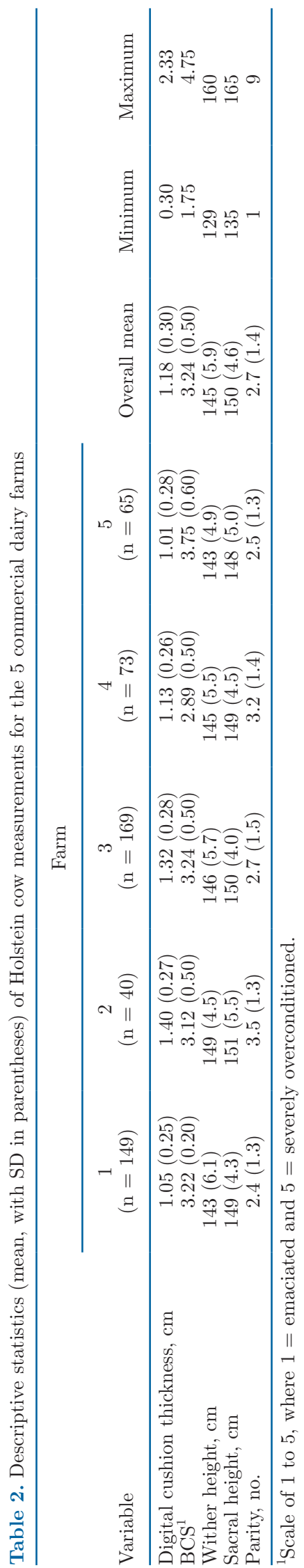

Variables Interacting with Parity Associated with $D C T$. Least squares means for DCT by DGT, BCSG, and wither height by parity are summarized in Table 4. Digital cushion thickness varied separately by DGT, BCSG, and wither height depending on parity $(P$ $<0.05)$. The DCT of the cows of average BCSG and cows with short wither height varied by parity group, with multiparous cows having thicker DCT $(P<0.05)$. Both parity groups had the thinnest DCT in the hind medial digit and the thickest DCT in the front medial digit $(P<0.05)$. Front lateral, hind medial, and hind lateral digits were different when compared between parity groups, with multiparous cows having thicker DCT than primiparous cows $(P<0.05)$. Only the front medial digit was not different between parity groups. For primiparous cows, cows of average BCSG had thinner DCT than cows of heavier BCSG $(P<0.05)$. For multiparous cows, cows of thin BCSG had thinner DCT than cows of average and heavier BCSG $(P<0.05)$.

Farm Variables by Parity Associated with $D C T$. Least squares means for DCT by farm management characteristics and parity are summarized in Table 5. Multiparous cows had thicker DCT than primiparous cows for 2 factors related to production, which were when the farm milked cows on a rotary parlor and the farm averaged $\leq 41 \mathrm{~kg} /$ cow per day $(P<$ 0.05). Furthermore, multiparous cows had thicker DCT than primiparous cows for elements related to cow comfort, such as when the freestalls were bedded with manure solids, rubber flooring was in the feeding alley, and farm employees had to manually scrape manure out of alleyways with skid loaders $(P<0.05)$. Last, multiparous cows had thicker DCT than primiparous cows for factors related to the prevention of lameness, including when the hoof trimmer used a standing chute, the footbath length was $<4 \mathrm{~m}$, the farm employees visually assessed and scored locomotion as a tool for detecting lameness, and the hoof trimmer was a trained farm employee $(P<0.05)$. Regarding both parity groups and bedding type, the cows with stalls bedded with sand had thicker DCT than the cows bedded with manure solids $(P<0.05)$. The digital cushion was thinner for both primiparous and multiparous cows when rubber was present in the feed alley of the barn $(P<0.05)$. Multiparous cows had thicker DCT when a veterinarian or employee was the hoof trimmer rather than when the trimmer was contracted $(P<0.05)$.

\section{GWAS}

Seventeen GWAS models were evaluated, and 13 models did not provide significant results after correction for multiple testing. Two GWAS identified the same SNP passing Bonferroni correction for multiple 
Table 3. Digital cushion thickness (DCT; LSM, with SEM in parentheses) per measurement time point and sacral height

\begin{tabular}{lccc}
\hline Variable and category & Observations, no. & DCT, cm & $P$-value \\
\hline Time point & & & $<0.001$ \\
$<137$ d prepartum & 496 & $1.21^{\mathrm{a}}(0.07)$ & \\
86-127 DIM & 446 & $1.16^{\mathrm{b}}(0.07)$ & $<0.001$ \\
Sacral height & & & \\
Short & 78 & $1.13^{\mathrm{b}}(0.07)$ & \\
Average & 190 & $1.17^{\mathrm{b}}(0.07)$ & \\
Tall & 221 & $1.21^{\mathrm{a}}(0.07)$ & \\
\hline
\end{tabular}

${ }^{a, b}$ Within a variable, category LSM with different superscripts are different at Tukey-Kramer adjusted $P<$ 0.05 .

${ }^{1}$ Assessed as the distance from the floor to the dorsal aspect of the caudal sacral joint. Short: $<145 \mathrm{~cm}$; average: $145-150 \mathrm{~cm}$; tall: $>150 \mathrm{~cm}$.

testing on BTA24 related to the quantitative measure of DCT. Another GWAS identified 22 SNP on BTA14, and a fourth GWAS identified 4 SNP on BTA29, with all SNP passing FDR. The models were the average DCT of the front medial digit, average DCT of the digits in the front foot, average DCT of the digits from the first time point, and average DCT of the digits from the second time point, respectively (Figures 2 and 3). BovineHD2400017222 on BTA24 was the only SNP in common among 2 of the 4 models, including the quantitative GWAS of the average front medial digit (Figure 2a), which is 1 of the 2 digits composing the quantitative GWAS of the average DCT of the digits in the front foot (Figure $2 \mathrm{~b}$ ), with Bonferroni-adjusted $P$-values of 0.01 and 0.02 . Overall, the $26 \mathrm{SNP}$ that passed FDR had an adjusted $P$-value range of 0.003 to 0.04 (Table 6).

The range of pseudo-lambda values for the 4 models with significant SNP was between 0.99 and 1.0, indicating limited stratification due to substructure. The SNP heritability estimates including the covariates of sequencing batch plate, parity group, BCS, wither height, and sacral height for the 4 models with significant SNP ranged from 0.27 to 0.33 with an average of $0.31 \pm 0.13$.

Linkage disequilibrium structure was evaluated for 27 markers that surpassed the Bonferroni-adjusted cutoff or FDR. Twenty-six of the 27 markers were in blocks of LD (Figure 4). Ten putative candidate genes were identified in the NCBI Genome Data Viewer ei-

Table 4. Digital cushion thickness (DCT; LSM, with SEM in parentheses) by digit, BCS group, and wither height for primiparous and multiparous cows

\begin{tabular}{|c|c|c|c|c|}
\hline \multirow{2}{*}{$\begin{array}{l}\text { Variable and } \\
\text { category }\end{array}$} & \multirow{2}{*}{$\begin{array}{c}\text { Cows, } \\
\text { no. }\end{array}$} & \multicolumn{2}{|c|}{$\mathrm{DCT}, \mathrm{cm}$} & \multirow[b]{2}{*}{$P$-value } \\
\hline & & Primiparous & Multiparous & \\
\hline Digit & & & & 0.006 \\
\hline Front medial & 496 & $1.19^{\mathrm{a}, \mathrm{y}}(0.07)$ & $1.26^{\mathrm{a}, \mathrm{y}}(0.07)$ & \\
\hline Front lateral & 496 & $1.13^{\mathrm{b}, \mathrm{y}}(0.07)$ & $1.21^{\mathrm{b}, \mathrm{z}}(0.07)$ & \\
\hline Hind medial & 493 & $0.99^{\mathrm{c}, \mathrm{y}}(0.07)$ & $1.13^{\mathrm{c}, \mathrm{z}}(0.07)$ & \\
\hline Hind lateral & 494 & $1.12^{\mathrm{b}, \mathrm{y}}(0.07)$ & $1.19^{\mathrm{b}, \mathrm{z}}(0.07)$ & \\
\hline BCS group ${ }^{1}$ & & & & 0.002 \\
\hline Thin & 166 & $1.17^{\mathrm{ab}, \mathrm{y}}(0.10)$ & $1.14^{\mathrm{b}, \mathrm{y}}(0.08)$ & \\
\hline Average & 179 & $1.08^{\mathrm{b}, \mathrm{y}}(0.08)$ & $1.21^{\mathrm{a}, \mathrm{z}}(0.08)$ & \\
\hline Fat & 101 & $1.21^{\mathrm{a}, \mathrm{y}}(0.08)$ & $1.24^{\mathrm{a}, \mathrm{y}}(0.08)$ & \\
\hline Wither height $^{2}$ & & & & 0.049 \\
\hline Short & 238 & $1.10^{\mathrm{a}, \mathrm{y}}(0.07)$ & $1.19^{\mathrm{a}, \mathrm{z}}(0.07)$ & \\
\hline Average & 160 & $1.22^{\mathrm{a}, \mathrm{y}}(0.09)$ & $1.19^{\mathrm{a}, \mathrm{y}}(0.07)$ & \\
\hline Tall & 91 & - & $1.22^{\mathrm{a}}(0.07)$ & \\
\hline
\end{tabular}

${ }^{\mathrm{a}-\mathrm{c}}$ Within a variable, category LSM with different superscripts are different at Tukey-Kramer adjusted $P<$ 0.05 .

${ }^{y, z}$ Within a variable, category across parity groups LSM with different superscripts are different at TukeyKramer adjusted $P<0.05$.

${ }^{1}$ Scale of 1 to 5 , where $1=$ emaciated and $5=$ severely overconditioned. Thin: BCS $<2.75$; average: BCS $2.75-3.25$; fat: $\mathrm{BCS}>3.25$.

${ }^{2}$ Assessed as the distance from withers to the dorsal aspect of the caudal sacral joint measured across the back. Short: $<145 \mathrm{~cm}$; average: $145-150 \mathrm{~cm}$; tall: $>150 \mathrm{~cm}$. 
Table 5. Digital cushion thickness (DCT; LSM, with SEM in parentheses) by farm management characteristics for primiparous and multiparous cows

\begin{tabular}{|c|c|c|c|c|}
\hline \multirow[b]{2}{*}{ Variable and category } & \multirow{2}{*}{$\begin{array}{c}\text { Farms, } \\
\text { no. }\end{array}$} & \multicolumn{2}{|c|}{$\mathrm{DCT}, \mathrm{cm}$} & \multirow[b]{2}{*}{$P$-value } \\
\hline & & Primiparous & Multiparous & \\
\hline \multicolumn{4}{|l|}{ Parlor type } & \multirow[t]{3}{*}{$<0.001$} \\
\hline Parallel & 4 & $1.20^{\mathrm{a}, \mathrm{y}}(0.09)$ & $1.22^{\mathrm{a}, \mathrm{y}}(0.09)$ & \\
\hline Rotary & 1 & $0.95^{\mathrm{a}, \mathrm{y}}(0.18)$ & $1.11^{\mathrm{a}, \mathrm{z}}(0.18)$ & \\
\hline \multicolumn{4}{|l|}{ Milk yield, $\mathrm{kg} / \mathrm{d}$} & \multirow[t]{3}{*}{$<0.001$} \\
\hline$\leq 41$ & 3 & $1.04^{\mathrm{a}, \mathrm{y}}(0.10)$ & $1.18^{\mathrm{a}, \mathrm{z}}(0.10)$ & \\
\hline$>41$ & 2 & $1.22^{\mathrm{a}, \mathrm{y}}(0.12)$ & $1.23^{\mathrm{a}, \mathrm{y}}(0.12)$ & \\
\hline \multicolumn{4}{|l|}{ Bedding type } & \multirow[t]{4}{*}{$<0.001$} \\
\hline Manure solids & 2 & $0.94^{\mathrm{b}, \mathrm{y}}(0.04)$ & $1.07^{\mathrm{b}, \mathrm{z}}(0.03)$ & \\
\hline Sand & 2 & $1.35^{\mathrm{a}, \mathrm{y}}(0.04)$ & $1.36^{\mathrm{a}, \mathrm{y}}(0.03)$ & \\
\hline Sawdust & 1 & - & $1.13^{\mathrm{b}}(0.05)$ & \\
\hline \multicolumn{4}{|l|}{ Rubber flooring } & \multirow[t]{3}{*}{$<0.001$} \\
\hline Yes & 3 & $0.96^{\mathrm{b}, \mathrm{y}}(0.03)$ & $1.09^{\mathrm{b}, \mathrm{z}}(0.03)$ & \\
\hline No & 2 & $1.35^{\mathrm{a}, \mathrm{y}}(0.04)$ & $1.36^{\mathrm{a}, \mathrm{y}}(0.03)$ & \\
\hline \multicolumn{4}{|l|}{ Scrape } & \multirow{3}{*}{$<0.001$} \\
\hline Manual & 3 & $1.04^{\mathrm{a}, \mathrm{y}}(0.10)$ & $1.18^{\mathrm{a}, \mathrm{z}}(0.10)$ & \\
\hline Automatic & 2 & $1.22^{\mathrm{a}, \mathrm{y}}(0.12)$ & $1.23^{\mathrm{a}, \mathrm{y}}(0.12)$ & \\
\hline \multicolumn{4}{|l|}{ Footbath length, m } & \multirow[t]{3}{*}{$<0.001$} \\
\hline$<4$ & 3 & $1.04^{\mathrm{a}, \mathrm{y}}(0.11)$ & $1.21^{\mathrm{a}, \mathrm{z}}(0.11)$ & \\
\hline$\geq 4$ & 2 & $1.15^{\mathrm{a}, \mathrm{y}}(0.13)$ & $1.17^{\mathrm{a}, \mathrm{y}}(0.13)$ & \\
\hline \multicolumn{4}{|l|}{$\mathrm{VL} S^{1}$} & \multirow[t]{3}{*}{$<0.001$} \\
\hline Yes & 3 & $1.04^{\mathrm{a}, \mathrm{y}}(0.11)$ & $1.21^{\mathrm{a}, \mathrm{z}}(0.11)$ & \\
\hline No & 2 & $1.15^{\mathrm{a}, \mathrm{y}}(0.13)$ & $1.17^{\mathrm{a}, \mathrm{y}}(0.13)$ & \\
\hline \multicolumn{4}{|l|}{ Chute type } & \multirow[t]{3}{*}{$<0.001$} \\
\hline Standing & 3 & $1.04^{\mathrm{a}, \mathrm{y}}(0.10)$ & $1.18^{\mathrm{a}, \mathrm{z}}(0.10)$ & \\
\hline Layover & 2 & $1.22^{\mathrm{a}, \mathrm{y}}(0.12)$ & $1.23^{\mathrm{a}, \mathrm{y}}(0.12)$ & \\
\hline \multicolumn{4}{|l|}{ Hoof trimmer } & \multirow[t]{4}{*}{0.009} \\
\hline Contracted & 2 & $1.03^{\mathrm{a}, \mathrm{y}}(0.06)$ & $1.07^{\mathrm{b}, \mathrm{y}}(0.05)$ & \\
\hline Farm employee & 1 & $0.95^{\mathrm{a}, \mathrm{y}}(0.07)$ & $1.11^{\mathrm{ab}, \mathrm{z}}(0.07)$ & \\
\hline Veterinarian & 1 & - & $1.40^{\mathrm{a}}(0.08)$ & \\
\hline
\end{tabular}

ther within the block of $\mathrm{LD}$ if $\mathrm{R}^{2}>0.80$ or within a $1-\mathrm{Mb}$ window centered on the significantly associated SNP (Table 7). Twenty-five of the 27 markers resided within genes. The putative candidate genes were $D L G 2$ and $M C_{4} R$, which function in bone resorption and fat deposition, respectively.

\section{DISCUSSION}

In our initial epidemiologic study of DCT, we characterized the variation in DCT across lactation in 177 cows and determined digital cushion risk factors associated with lameness and key time points when the digital cushion is thickest or thinnest (Stambuk et al., 2019). The current analysis evaluated 496 cows from 5 farms, more than tripling the number of individuals in our analysis by focusing on these 2 time points. This allowed us to corroborate our phenotypic results in a larger cohort across multiple farms and build a data set more appropriate for genetic analysis. The smaller sample size used for conducting GWAS was likely mitigated with direct phenotypic measures on the cows, thereby reducing phenotypic error. All genetic models had sufficient effective sample sizes to achieve $80 \%$ power, which is commonly used to avoid false-negative associations and to determine a cost-effective sample size (Hong and Park, 2012). A genome-wide investigation of DCT provides an opportunity to understand the underlying biological mechanisms influencing the digital cushion.

Further investigation into the functions of the candidate genes for DCT revealed 2 biologically plausible genes related to fat tissue deposition and bone growth. Located on BTA24, $M C 4 R$ is a major controller of feed intake and energy expenditure, and mutations in this gene have been related to back fat thickness, marbling, and carcass and live weight in cattle (Huang et al., 2010; Liu et al., 2010; Seong et al., 2012; Switonski et al., 2013); $M C 4 R$ was identified as a candidate gene for the average front medial digit and average DCT of the digits in the front foot, which includes the front medial digit GWAS models. The digital cushion consists of mostly adipose tissue, and this study determined 
(a)

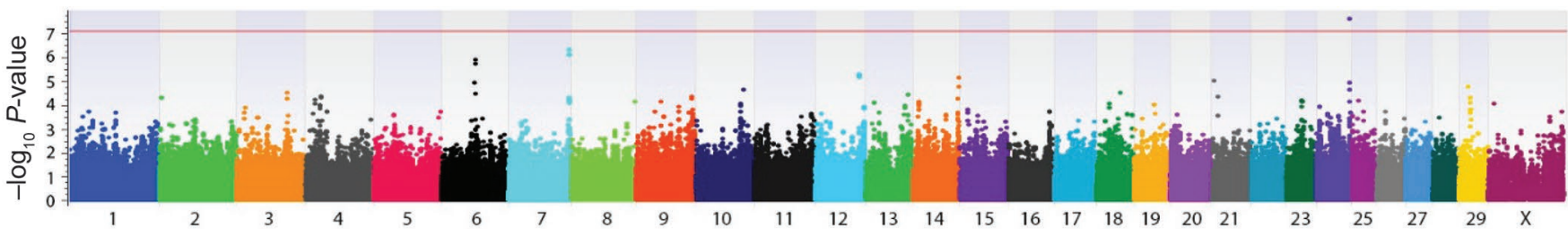

(b)

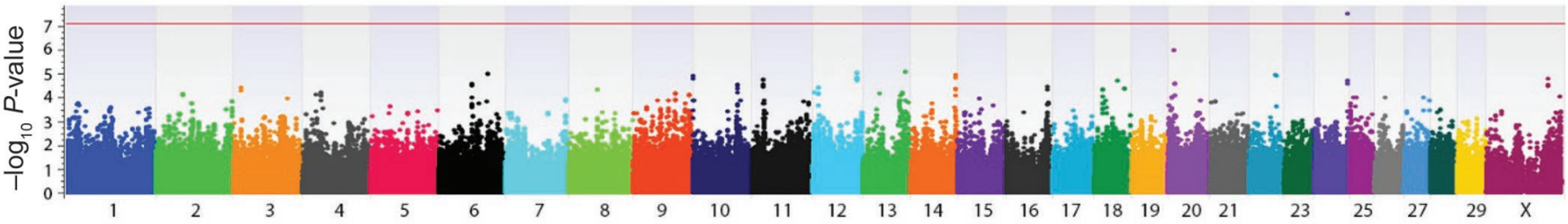

(c)

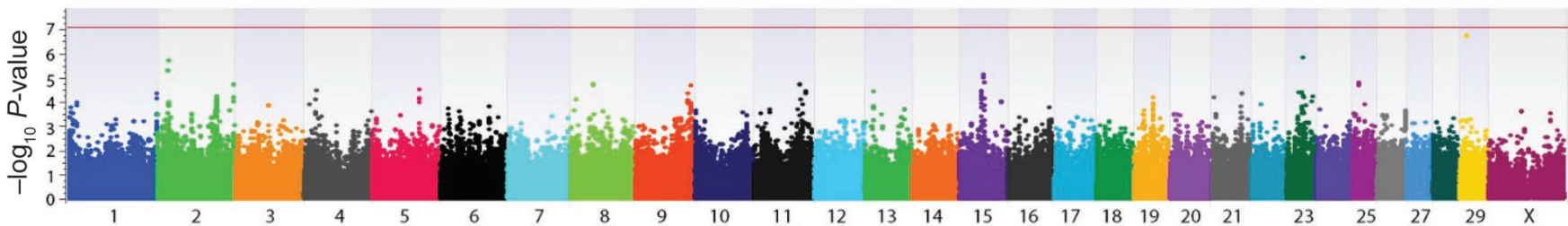

(d)

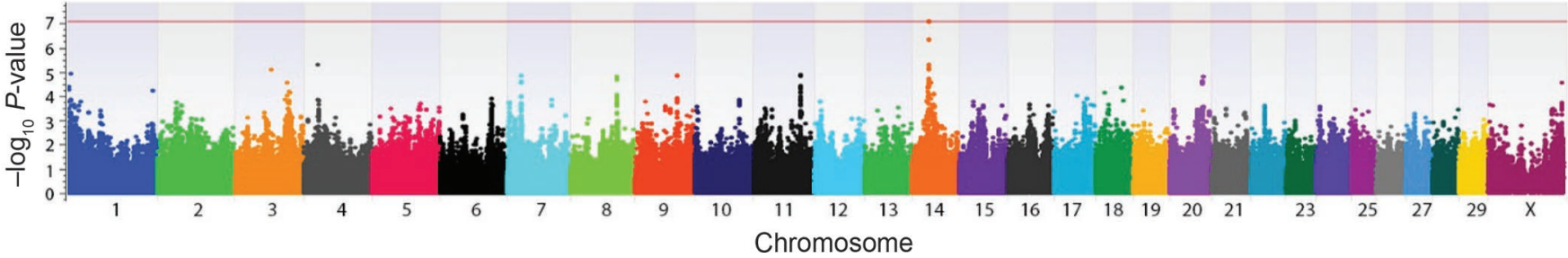

Figure 2. Manhattan plots for digital cushion thickness by (a) average front medial digit, (b) average front foot, (c) average of time point 1 measurements at $<137 \mathrm{~d}$ prepartum, and (d) average of time point 2 measurements at 86 to 127 DIM. The red horizontal line indicates the Bonferroni-adjusted $P$-value threshold of $<0.05$.

the front medial digit to be thickest for both parity groups (Räber et al., 2004). Furthermore, the digits of the front feet have been shown to contain more fat than the digits in the hind feet (Räber et al., 2004). It is biologically plausible that $M C 4 R$ is affecting DCT through fat tissue accumulation.

All 4 markers that passed FDR for the average DCT of time point 1 measurements when the digital cushion is thickest were annotated in DLG2, located on BTA29. Structural variant mutations in this gene are involved with osteosarcoma, with $D L G 2$ deletions accelerating bone tumor growth in canine and human cell lines (Chen et al., 2014; Shao et al., 2019). A study by Newsome et al. (2016) suggested that bone development on the caudal aspect of the distal phalanx affects CHDL, which is genetically correlated with DCT (Oikonomou et al., 2014). Potentially, mutations in $D L G 2$ could be influencing bone development in the distal phalanx, thereby affecting the thickness of the digital cushion. On average, time point 1 was $<2$ mo before calving, when cows are of greater body mass than in lactation due to the growing fetus as the cow gets closer to partu- rition. Therefore, it is biologically plausible that $D L G 2$ has a greater influence on DCT at time point 1 due to the increase in pressure exerted on the digital cushion during that period.

The heritability of DCT based on the 4 GWAS models with significant SNP was found to be similar to previous research. The average heritability in the current study was $0.31 \pm 0.13$ (with a likely inflated standard error due to the low sample size) when accounting for the covariates of sequencing batch plate, parity group, BCS, wither height, and sacral height used in the GWAS models. This is similar to but slightly less than the $0.33 \pm 0.09$ estimated by Oikonomou et al. (2014). The difference could be due to the methods of determining heritability, population differences, and covariates included in the model. The current study determined heritability based on the additive effects of a given set of SNP, whereas Oikonomou et al. (2014) determined heritability based on the estimates of variance components from a univariate pedigree animal model analysis. Additionally, the current study defined DCT multiple ways and included measurements from the front foot, 

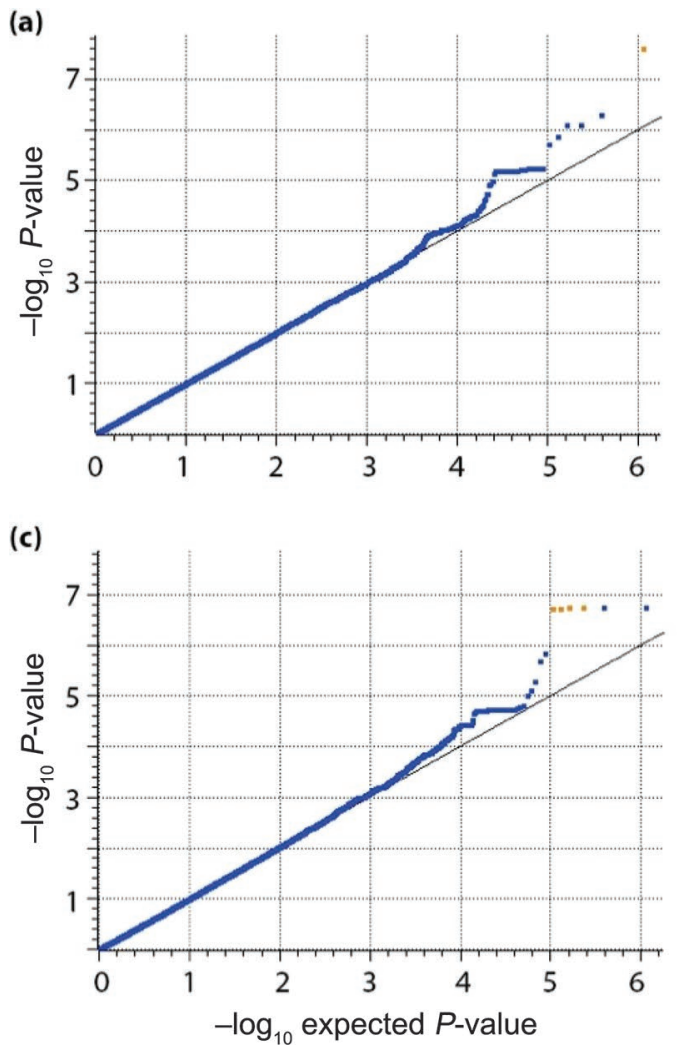

(b)

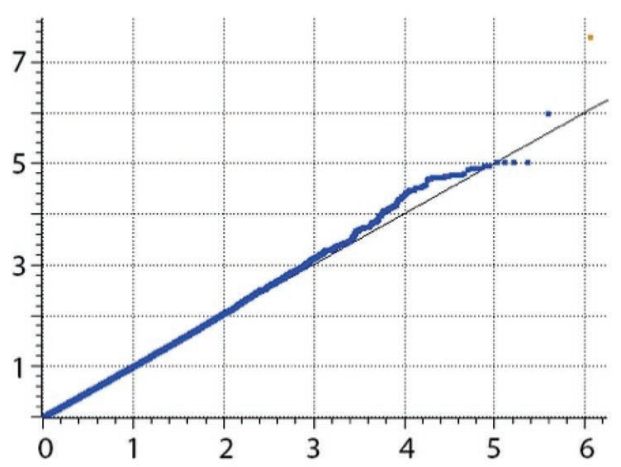

(d)

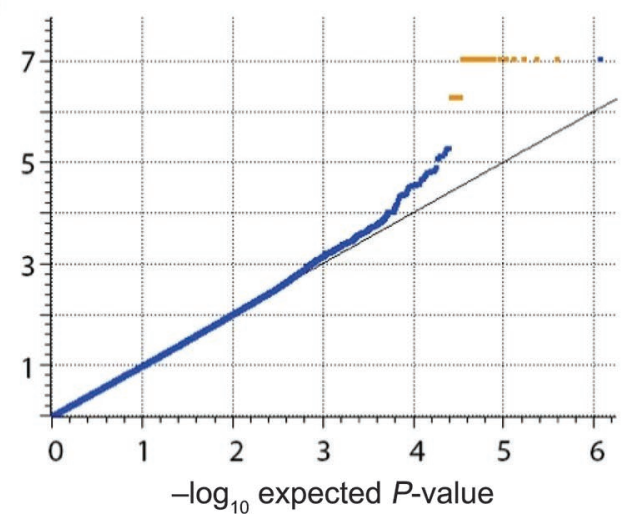

Figure 3. Quantile-quantile plots of digital cushion thickness by (a) average front medial digit, (b) average front foot, (c) average of time point 1 measurements at $<137 \mathrm{~d}$ prepartum, and (d) average of time point 2 measurements at 86 to 127 DIM. The blue squares are markers that had a false discovery rate $P$-value of $\geq 0.05$, and the orange squares are markers that had a false discovery rate $P$-value of $<0.05$.

whereas Oikonomou et al. (2014) defined DCT only as an average of all measurements, with some cows having only the 4 hind digits.

Only 1 other study has focused on the genetics of the digital cushion. Iqbal et al. (2016) investigated key genes associated with insulin signaling, carbohydrate metabolism, adipogenic and lipogenic transcription regulators, and regulation of lipolysis and their expression in the digital cushion of 14 nonpregnant, nonlactating Holstein cows fed either high- or low-energy diets. Their goal was to relate target gene expression to the amount of energy in the diets. They found lipogenic genes to be consistently upregulated when feeding the higher energy diet. None of the 27 genes investigated by Iqbal et al. (2016) were candidate genes in the current study. However, that study was fundamentally different from ours, in which we used GWAS to identify candidate genes associated with DCT as opposed to gene expression in the digital cushion related to diet.

This was the first study to evaluate DCT with different farm characteristics. Knowing the association of management practices with DCT allows producers to make better informed decisions related to hoof health and lameness prevention given the relationship of DCT to lameness (Bicalho et al., 2009; Stambuk et al., 2019). For instance, the digital cushion was thicker when the freestalls were deep bedded with sand or when rubber was not in the feeding alley. However, these 2 management practices cannot be differentiated from one another because the farms that did not have rubber in the feeding alley of the pens were the farms that bedded with sand. Deep bedding with sand reduces the likelihood of a lame event, whereas results for rubber usage have been inconsistent (Andreasen and Forkman, 2012). Studies have reported beneficial effects, whereas others have reported adverse effects such as increased incidence of sole ulcers (Vanegas et al., 2006; Kremer et al., 2007). Instead of increasing the time spent feeding, rubber in the feed area significantly increased the time spent standing in the feed area and reduced time spent lying down (Fregonesi et al., 2004; Tucker et al., 2006).

Similar to Stambuk et al. (2019), DCT varied by claw and parity group, with the hind medial digit being the thinnest in both parity groups. As noted before, we performed our analyses with and without the $35 \%$ of cows represented in Stambuk et al. (2019) that were also within this data set and found the same biological and statistical differences in our outcomes and there- 


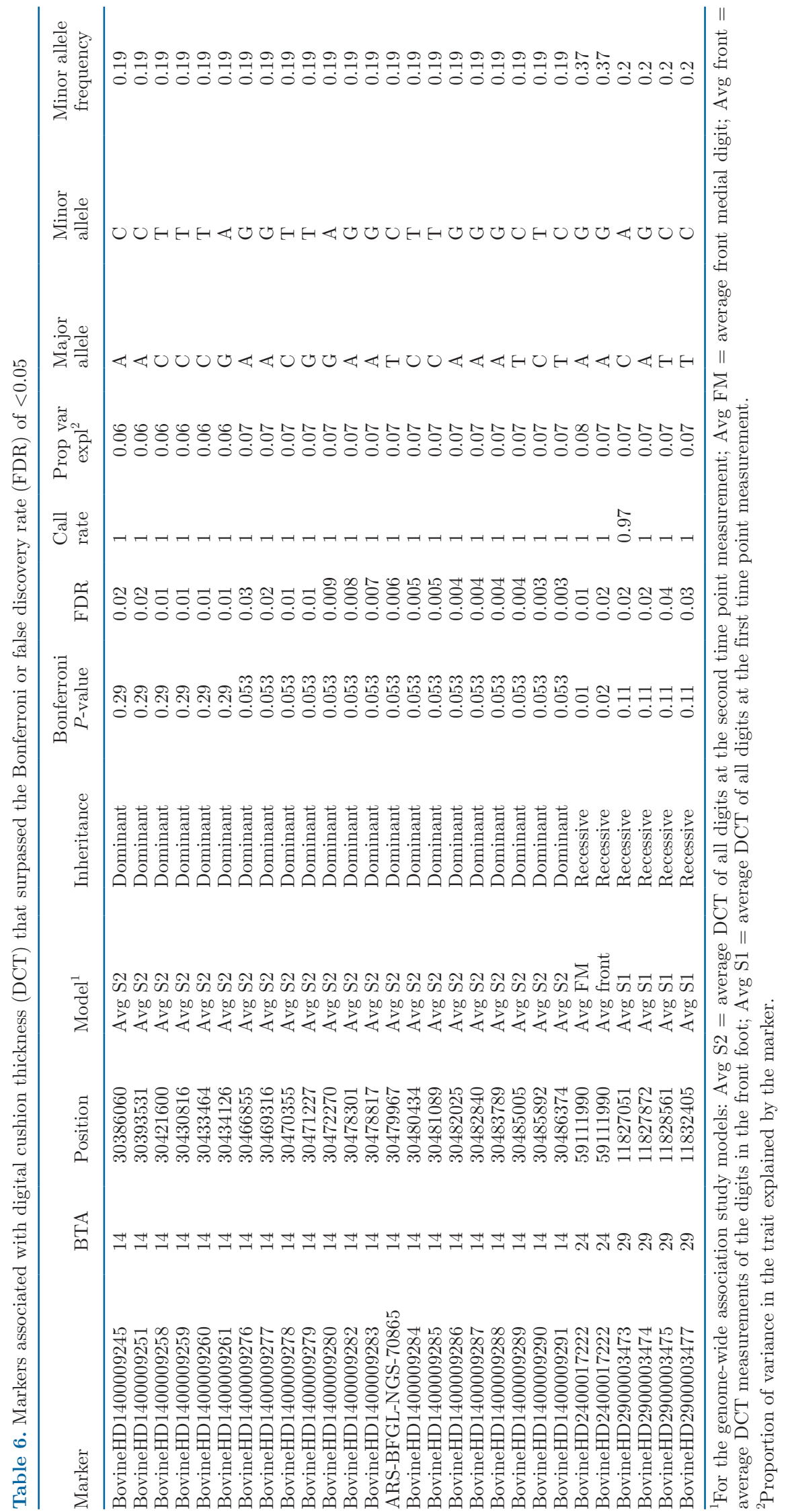


fore included these cows in our final analysis. This study determined the front medial digit to be thickest for both parity groups, whereas Stambuk et al. (2019) found only the front medial digit to be thickest for primiparous cows. Conformational similarity of claw and sole length between the front medial claw and hind lateral claw may provide some insight into our previous findings that the hind lateral claw was thickest for the multiparous cows (Nuss et al., 2011; Stambuk et al., 2019). Furthermore, the current study was able to evaluate variation in DCT within a larger number of Holstein cows and multiple farms. The previous study was conducted on 177 cows from 1 farm, whereas the current study evaluated 496 cows from 5 farms (Stambuk et al., 2019).

Cows that had tall sacral height had thicker DCT than those that had short or average sacral height. Newsome et al. (2017a) found a similar correlation between DCT and wither height in 179 cows in the United Kingdom that were mostly Holsteins in their first through fourth lactations. The current study found wither height to be different between parity groups, potentially reflecting differences in DCT based on the relationship of height, age, and geography. Multiparous cows of short stature had thicker DCT than primiparous cows of the same stature. The correlation in the current study of sacral height and wither height was 0.63 ; therefore, results for DCT were expected to be similar for sacral height and wither height for Holstein cows.

Additionally, this study found a relationship between BCSG and DCT. This agrees with Bicalho et al. (2009) and Machado et al. (2011), who reported DCT to be positively associated with BCS, increasing as BCS increased due to the added fat reserves. However, our previous study and Newsome et al. (2017a) did not find a relationship between BCS and DCT (Stambuk et al., 2019). The contradicting results could be due to sample size and differences in populations. The current study, Bicalho et al. (2009), and Machado et al. (2011) have a comparable number of cows $(496,501$, and 574 , respectively) but vary in the number of farms assessed $(5,1$, and 1 , respectively).

\section{CONCLUSIONS}

The first part of this study determined that DCT varied depending on farm management practices, parity, stage in lactation, digit, BCS group, wither height, and sacral height. The second part of the study used those results by including covariates, such as parity group, BCS, wither height, and sacral height, in the GWAS on DCT. From the genetic results, 27 genetic markers on BTA14, BTA24, and BTA29 were assessed for candidate genes associated with DCT. The 2 candidate genes highlighted were related to fat accumulation and bone development. Due to the skills, time commitment, and equipment needed to measure the digital cushion, as well as the potential stress to the animals from collecting the data on a routine basis, a long-term goal of this study was to identify markers for use in genomic selection to reduce lameness. Adding markers associated with DCT to the breeding program is easier to implement on a farm that is already genotyping than collecting the physical measurements of the

(a)

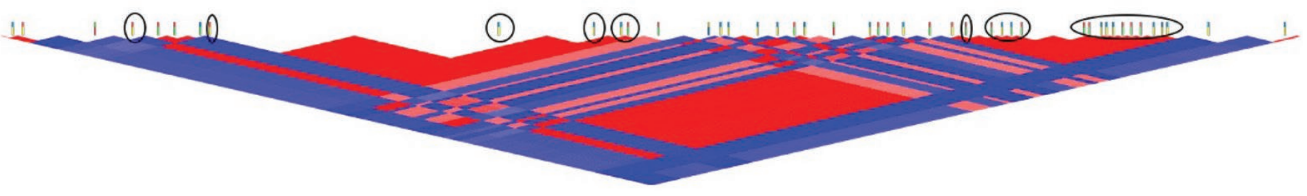

(b)

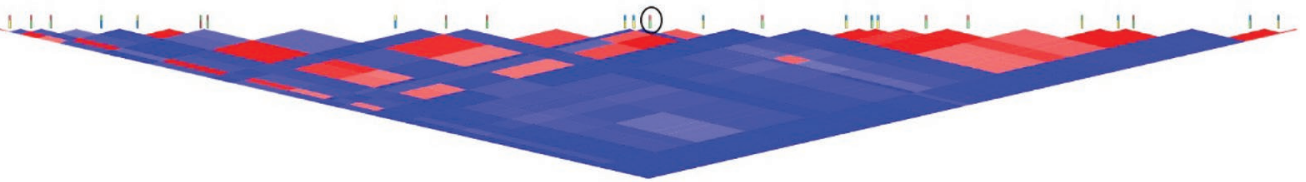

(c)

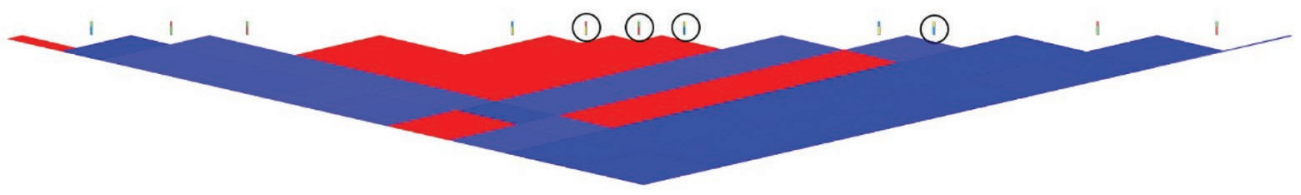

Figure 4. Linkage disequilibrium plots for blocks (a) BTA14:30386060-30486374, (b) BTA24:59611990-58611990, and (c) BTA29: 11821859-11832405 containing markers that passed Bonferroni-adjusted significance threshold or false discovery rate. The circles correspond to the location of the 27 significant markers evaluated for candidate genes. The colors represent correlation between 2 alleles, with blue shading for $\mathrm{R}^{2}<0.50$ and red shading for $\mathrm{R}^{2}>0.50$, with the shading darkening as the value reaches the extremes of 0 and 1 . 
digital cushion. Further research is needed to validate the results in an unrelated population, evaluate how exactly the candidate genes mentioned influence the DCT and function, and how the genetic markers would be used for genomic selection to reduce lameness.

\section{ACKNOWLEDGMENTS}

The authors thank the farms for their cooperation and access to their facilities during the study as well as Christian Posbergh (Department of Animal Science, Cornell University, Ithaca, NY) and the Cornell Statistical Consulting Unit (Ithaca, NY). This research project was funded by the USDA National Institute of Food and Agriculture (Washington, DC) Federal Formula Funds Hatch Project no. 2015-16-117. The authors confirm that there is no conflict of interest with this study.

\section{REFERENCES}

Andreasen, S. N., and B. Forkman. 2012. The welfare of dairy cows is improved in relation to cleanliness and integument alterations on the hocks and lameness when sand is used as stall surface. J. Dairy Sci. 95:4961-4967. https://doi.org/10.3168/jds.2011-5169.

Bicalho, R. C., V. S. Machado, and L. S. Caixeta. 2009. Lameness in dairy cattle: A debilitating disease or a disease of debilitated cattle? A cross-sectional study of lameness prevalence and thickness of the digital cushion. J. Dairy Sci. 92:3175-3184. https://doi .org/10.3168/jds.2008-1827.

Chen, X., A. Bahrami, A. Pappo, J. Easton, J. Dalton, E. Hedlund, D. Ellison, S. Shurtleff, G. Wu, L. Wei, M. Parker, M. Rusch, P. Nagahawatte, J. Wu, S. Mao, K. Boggs, H. Mulder, D. Yergeau, C. Lu, L. Ding, M. Edmonson, C. Qu, J. Wang, Y. Li, F. Navid, N. C. Daw, E. R. Mardis, R. K. Wilson, J. R. Downing, J. Zhang, and M. A. Dyer. 2014. Recurrent somatic structural variations contribute to tumorigenesis in pediatric osteosarcoma. Cell Rep. 7:104-112. https://doi.org/10.1016/j.celrep.2014.03.003.

Edmonson, A. J., I. J. Lean, L. D. Weaver, T. Farver, and G. Webster. 1989. A body condition scoring chart for Holstein dairy cows. J. Dairy Sci. 72:68-78. https://doi.org/10.3168/jds.S0022 -0302(89)79081-0

Fregonesi, J. A., C. B. Tucker, D. M. Weary, F. C. Flower, and T. Vittie. 2004. Effect of rubber flooring in front of the feed bunk on the time budgets of dairy cattle. J. Dairy Sci. 87:1203-1207. https:// doi.org/10.3168/jds.S0022-0302(04)73270-1.

Heringstad, B., C. Egger-Danner, N. Charfeddine, J. E. Pryce, K. F. Stock, J. Kofler, A. M. Sogstad, M. Holzhauer, A. Fiedler, K. Müller, P. Nielsen, G. Thomas, N. Gengler, G. de Jong, C. Ødegård, F. Malchiodi, F. Miglior, M. Alsaaod, and J. B. Cole. 2018. Invited review: Genetics and claw health: Opportunities to enhance claw health by genetic selection. J. Dairy Sci. 101:4801-4821. https:// doi.org/10.3168/jds.2017-13531.

Hong, E. P., and J. W. Park. 2012. Sample size and statistical power calculation in genetic association studies. Genomics Inform 10:117-122. https://doi.org/10.5808/GI.2012.10.2.117.

Hou, K., K. S. Burch, A. Majumdar, H. Shi, N. Mancuso, Y. Wu, S. Sankararaman, and B. Pasaniuc. 2019. Accurate estimation of SNP-heritability from biobank-scale data irrespective of genetic architecture. Nat. Genet. 51:1244-1251. https://doi.org/10.1038/ s41588-019-0465-0.

Huang, M., X. Gao, J. Y. Li, H. Y. Ren, J. B. Chen, and S. Z. Xu. 2010. Polymorphisms in MC4R gene and correlations with economic traits in cattle. Mol. Biol. Rep. 37:3941-3944. https://doi .org/10.1007/s11033-010-0051-0. 
Iqbal, Z. M., H. Akbar, A. Hosseini, E. Bichi Ruspoli Forteguerri, J. S. Osorio, and J. J. Loor. 2016. Digital cushion fatty acid composition and lipid metabolism gene network expression in Holstein dairy cows fed a high-energy diet. PLoS One 11:e0159536. https:/ /doi.org/10.1371/journal.pone.0159536.

Kang, H. M., J. H. Sul, S. K. Service, N. A. Zaitlen, S. Y. Kong, N. B. Freimer, C. Sabatti, and E. Eskin. 2010. Variance component model to account for sample structure in genome-wide association studies. Nat. Genet. 42:348-354. https://doi.org/10.1038/ng.548.

Kang, H. M., N. A. Zaitlen, C. M. Wade, A. Kirby, D. Heckerman, M. J. Daly, and E. Eskin. 2008. Efficient control of population structure in model organism association mapping. Genetics 178:17091723. https://doi.org/10.1534/genetics.107.080101.

Kennedy, B. W., M. Quinton, and J. A. M. van Arendonk. 1992. Estimation of effects of single genes on quantitative traits. J. Anim. Sci. 70:2000-2012. https://doi.org/10.2527/1992.7072000x.

Kremer, P. V., S. Nueske, A. M. Scholz, and M. Foerster. 2007. Comparison of claw health and milk yield in dairy cows on elastic or concrete flooring. J. Dairy Sci. 90:4603-4611. https://doi.org/10 .3168/jds.2006-549.

Lischer, C. J., P. Ossent, M. Räber, and H. Geyer. 2002. Suspensory structures and supporting tissues of the third phalanx of cows and their relevance to the development of typical sole ulcers (Rusterholz ulcers). Vet. Rec. 151:694-698. https://doi.org/10.1136/vr 151.23.694.

Littell, R. C., P. R. Henry, and C. B. Ammerman. 1998. Statistical analysis of repeated measures data using SAS procedures. J. Anim. Sci. 76:1216-1231. https://doi.org/10.2527/1998.7641216x.

Liu, H., W. Tian, L. Zan, H. Wang, and H. Cui. 2010. Mutations of MC4R gene and its association with economic traits in Qinchuan cattle. Mol. Biol. Rep. 37:535-540. https://doi.org/10.1007/s11033 $-009-9706-0$

Machado, V. S., L. S. Caixeta, and R. C. Bicalho. 2011. Use of data collected at cessation of lactation to predict incidence of sole ulcers and white line disease during the subsequent lactation in dairy cows. Am. J. Vet. Res. 72:1338-1343. https://doi.org/10.2460/ajvr .72 .10 .1338 .

Mülling, C. K. W., and P. R. Greenough. 2006. Applied physiopathology of the foot. Pages 103-117 in XXIV World Buiatrics Congress, Nice, France. World Association for Buiatrics, Paris, France.

Murray, R. D., D. Y. Downham, M. J. Clarkson, W. B. Faull, J. W. Hughes, F. J. Manson, J. B. Merritt, W. B. Russell, J. E. Sutherst, and W. R. Ward. 1996. Epidemiology of lameness in dairy cattle: Description and analysis of foot lesions. Vet. Rec. 138:586-591. https://doi.org/10.1136/vr.138.24.586.

Newsome, R., M. J. Green, N. J. Bell, M. G. G. Chagunda, C. S. Mason, C. S. Rutland, C. J. Sturrock, H. R. Whay, and J. N. Huxley. 2016. Linking bone development on the caudal aspect of the distal phalanx with lameness during life. J. Dairy Sci. 99:4512-4525. https://doi.org/10.3168/jds.2015-10202.

Newsome, R. F., M. J. Green, N. J. Bell, N. J. Bollard, C. S. Mason, H. R. Whay, and J. N. Huxley. 2017a. A prospective cohort study of digital cushion and corium thickness. Part 1: Associations with body condition, lesion incidence, and proximity to calving. J. Dairy Sci. 100:4745-4758. https://doi.org/10.3168/jds.2016-12012.

Newsome, R. F., M. J. Green, N. J. Bell, N. J. Bollard, C. S. Mason, H. R. Whay, and J. N. Huxley. 2017b. A prospective cohort study of digital cushion and corium thickness. Part 2: Does thinning of the digital cushion and corium lead to lameness and claw horn disruption lesions? J. Dairy Sci. 100:4759-4771. https://doi.org/ $10.3168 /$ jds.2016-12012.

Nuss, K., C. Sauter-Louis, and B. Sigmund. 2011. Measurements of forelimb claw dimensions in cows using a standardised sole thickness: A post-mortem study. Vet. J. 190:84-89. https://doi.org/10 $.1016 /$ j.tvjl.2010.10.002.

Oikonomou, G., G. Banos, V. Machado, L. Caixeta, and R. C. Bicalho. 2014. Genetic characterization of digital cushion thickness. J. Dairy Sci. 97:532-536. https://doi.org/10.3168/jds.2013-7212.
Oikonomou, G., N. B. Cook, and R. C. Bicalho. 2013. Sire predicted transmitting ability for conformation and yield traits and previous lactation incidence of foot lesions as risk factors for the incidence of foot lesions in Holstein cows. J. Dairy Sci. 96:3713-3722. https: //doi.org/10.3168/jds.2012-6308.

Purcell, S., B. Neale, K. Todd-Brown, L. Thomas, M. A. Ferreira, D. Bender, J. Maller, P. Sklar, P. I. de Bakker, M. J. Daly, and P. C. Sham. 2007. PLINK: A tool set for whole-genome association and population-based linkage analyses. Am. J. Hum. Genet. 81:559-575. https://doi.org/10.1086/519795.

Räber, M., C. Lischer, H. Geyer, and P. Ossent. 2004. The bovine digital cushion-A descriptive anatomical study. Vet. J. 167:258-264. https://doi.org/10.1016/S1090-0233(03)00053-4.

Seong, J., D. S. Suh, K. D. Park, H. K. Lee, and H. S. Kong. 2012. Identification and analysis of MC4R polymorphisms and their association with economic traits of Korean cattle (Hanwoo). Mol. Biol. Rep. 39:3597-3601. https://doi.org/10.1007/s11033-011-1133 -3 .

Shao, Y. W., G. A. Wood, J. Lu, Q. Tang, J. Liu, S. Molyneux, Y. Chen, H. Fang, H. Adissu, T. McKee, P. Waterhouse, and R. Khokha. 2019. Cross-species genomics identifies DLG2 as a tumor suppressor in osteosarcoma. Oncogene 38:291-298. https:// doi.org/10.1038/s41388-018-0444-4.

Shearer, J. K., P. J. Plummer, and J. A. Schleining. 2015. Perspectives on the treatment of claw lesions in cattle. Vet. Med. (Auckl.) 6:273-292. https://doi.org/10.2147/VMRR.S62071.

Sprecher, D. J., D. E. Hostetler, and J. B. Kaneene. 1997. A lameness scoring system that uses posture and gait to predict dairy cattle reproductive performance. Theriogenology 47:1179-1187. https:// doi.org/10.1016/s0093-691x(97)00098-8.

Stambuk, C. R., J. A. A. McArt, B. C. Bicalho, A. M. Miles, and H. J. Huson. 2019. A longitudinal study of digital cushion thickness and its function as a predictor for compromised locomotion and hoof lesions in Holstein cows. Transl. Anim. Sci. 3:74-83. https:// doi.org/10.1093/tas/txy107.

Switonski, M., M. Mankowska, and S. Salamon. 2013. Family of melanocortin receptor (MCR) genes in mammals-Mutations, polymorphisms and phenotypic effects. J. Appl. Genet. 54:461-472. https://doi.org/10.1007/s13353-013-0163-z.

Tucker, C. B., D. M. Weary, A. M. de Passille, B. Campbell, and J. Rushen. 2006. Flooring in front of the feed bunk affects feeding behavior and use of freestalls by dairy cows. J. Dairy Sci. 89:20652071. https://doi.org/10.3168/jds.S0022-0302(06)72274-3.

Vanegas, J., M. Overton, S. L. Berry, and W. M. Sischo. 2006. Effect of rubber flooring on claw health in lactating dairy cows housed in free-stall barns. J. Dairy Sci. 89:4251-4258. https://doi.org/10 .3168/jds.S0022-0302(06)72471-7.

Visscher, P. M., G. Hemani, A. A. E. Vinkhuyzen, G. B. Chen, S. H. Lee, N. R. Wray, M. E. Goddard, and J. Yang. 2014. Statistical power to detect genetic (co)variance of complex traits using SNP data in unrelated samples. PLoS Genet. 10:e1004269. https://doi .org/10.1371/journal.pgen.1004269.

Yang, J., S. H. Lee, M. L. Goddard, and P. M. Visscher. 2011. GCTA: A tool for genome-wide complex trait analysis. Am. J. Hum. Genet. 88:76-82. https://doi.org/10.1016/j.ajhg.2010.11.011.

Zaitlen, N., and P. Kraft. 2012. Heritability in the genome-wide association era. Hum. Genet. 131:1655-1664. https://doi.org/10.1007/ s00439-012-1199-6.

\section{ORCIDS}

C. R. Stambuk @ https://orcid.org/0000-0003-0652-8669

E. A. Staiger (1) https://orcid.org/0000-0002-5677-0798

A. Nazari-Ghadikolaei @ https://orcid.org/0000-0001-5092-8788

B. J. Heins (ํ) https://orcid.org/0000-0003-2186-9082

H. J. Huson ๑ https://orcid.org/0000-0001-8299-0447 